\title{
The Value of Econometrics to Economists in Business and Government: A Study of the State of the Discipline
}

\author{
ERIC R. SOWEY ${ }^{\dagger}$ \\ e.sowey@unsw.edu.au \\ School of Economics, The University of New South Wales, Sydney, NSW 2052 Australia
}

\begin{abstract}
This paper is the first ever in-depth study of the econometric practice of quantitative economists outside academia. It goes further, to examine empirically the often-heard proposition that academic and nonacademic economists nowadays seem to analyse the same applied quantitative problems in markedly separate ways. Nine indicators of separation between the approaches of 'town' and 'gown' economists are developed. The study rests on detailed interviews with 50 nonacademic economists drawn widely from a single area of professional activity: the Australian housing sector. These economists' use of econometric methods, and their views on the value of these methods, are documented and compared with the academic approach to applied econometric work, as reported in the scholarly literature. The evidence on the nine indicators supports the existence of a state of separation. The paper points to some undesirable consequences of separation and concludes with practical ideas on what should be done about it. There are lessons in the findings of this study for the future of other quantitative disciplines that are widely practised in government, business and industry.
\end{abstract}

Keywords: quantitative economics; the future of applied economics

\section{Introduction}

"The economics profession has divided itself into three groups: (i) the public sector economists; (ii) the private sector economists; and (iii) the academic economists; with each group tending to have ... its own ideologies, modes of thinking and methodologies. In practice, there is little interaction or close links among the three."

So runs a publisher's blurb for the journal Economic and Financial Review, which offers to reunite the separated parties. If what this quotation asserts is correct, then we are witnessing a significant development in the discipline of economics. It is a development noted also by others, for example Hutchison (1992), Motamen-Scobie (1992) and Hagen (1994), and echoed

$\dagger$ Requests for reprints should be sent to Eric R. Sowey, School of Economics, The University of New South Wales, Sydney, NSW 2052, Australia. 
in the field of statistics by, for example, Banks (1993), Iman (1994) and Bailar (1995).

What these writers declare - that there is a tendency to separateness in the ways in which the same issues are approached by professionals (whether they be economists or statisticians) in business and government and in academia - is not entirely new. It was already discussed anecdotally, for example, by Henderson (1986) in the field of economics and by Moser (1980) in the field of statistics.

What is new is the rate of progress of separation: more and more, the discipline seems to be carried forward independently in each arena, and it seems to be no-one's responsibility to see to it that what evolves is good for the future of the discipline as a whole. The urgent implication is that this separateness is rapidly approaching what might best be described as a split, with practitioners in each arena aware that there are people in the other, but from whose professional activity they feel quite detached.

What is remarked on in the fields of economics and statistics should be all the more apparent in their field of intersection: econometrics. It is the situation in econometrics that I shall examine in this paper.

\section{Econometrics in 'Town' and 'Gown'}

In this, the first ever in-depth study of the econometric practice of nonacademic economists, I analyse the way economists in business and government currently approach their econometric work, and compare this with the approach of applied economists researching in academia.

What might be some indicators of separation between applied econometric work in 'town' and 'gown'? Table 1 contrasts six work characteristics of economists in business and government and economists in academia, in particular as to their use of econometric methods.

From this contrast of work characteristics, I have distilled in Table 2 a set of nine 'separation indicators' that distinguish the work of 'town' economists and their use of econometrics from those of academic economists. The work characteristic from which each indicator is drawn is shown in the last column of this table.

If there were a common mode in which academic economists and business and government economists reported their econometric work, an analysis of the output in this common mode would be all that would be required to make a comparison. However, whereas academic economists ${ }^{1}$ communicate their work almost exclusively at professional conferences and in scholarly publications, there is a much broader (and different) array of means by which nonacademic economists report their professional analyses. Internal 
Table 1. Six work characteristics

\begin{tabular}{|c|c|c|c|}
\hline & Characteristic & 'Town' economists & 'Gown' economists \\
\hline A & $\begin{array}{l}\text { Choice of } \\
\text { project }\end{array}$ & $\begin{array}{l}\text { Projects are usually prescribed by oth- } \\
\text { ers. The variety of projects tends } \\
\text { to be limited. The same project } \\
\text { (e.g. short-term prediction of mar- } \\
\text { ket conditions) is often duplicated by } \\
\text { economists in several organisations. }\end{array}$ & $\begin{array}{l}\text { The subject and scope of research, and } \\
\text { hence its variety, generally rests with } \\
\text { the researcher. Duplication of effort } \\
\text { tends to be avoided as far as possible. }\end{array}$ \\
\hline B & Time available & $\begin{array}{l}\text { Deadlines are usually short, and often } \\
\text { very short. }\end{array}$ & $\begin{array}{l}\text { Funding bodies may impose deadlines, } \\
\text { but they are not usually short. }\end{array}$ \\
\hline $\mathrm{C}$ & $\begin{array}{l}\text { Realism and } \\
\text { responsibility }\end{array}$ & $\begin{array}{l}\text { Commentaries and advice are liable to } \\
\text { be acted upon by others promptly and } \\
\text { often with commitment of large sums } \\
\text { of money. This demands that insti- } \\
\text { tutional realism be given precedence } \\
\text { over generality of analysis. Further, } \\
\text { the availability, reliability and timeli- } \\
\text { ness of data become of major concern. }\end{array}$ & $\begin{array}{l}\text { Modelling work is not generally for } \\
\text { specific or immediate policy applica- } \\
\text { tion. Particular institutional com- } \\
\text { plexities and data deficiencies need } \\
\text { not, therefore, assume major signifi- } \\
\text { cance. }\end{array}$ \\
\hline D & Quality control & $\begin{array}{l}\text { There is little chance that analytical } \\
\text { errors will be detected and corrected } \\
\text { by clients, since they generally lack } \\
\text { the economist's technical skills. }\end{array}$ & $\begin{array}{l}\text { Academic referees (prior to publica- } \\
\text { tion) and journal readers (after pub- } \\
\text { lication) are stringent and informed } \\
\text { critics. }\end{array}$ \\
\hline $\mathrm{E}$ & $\begin{array}{l}\text { Choice of } \\
\text { techniques }\end{array}$ & $\begin{array}{l}\text { The focus is on problem-solving for } \\
\text { the real world. Clients' interest } \\
\text { is in the solutions: they do not } \\
\text { seek evidence that some particular } \\
\text { professionally-approved set of tools } \\
\text { has been used. Short deadlines mean } \\
\text { that judgmental methods may be sub- } \\
\text { stituted for time-demanding formal } \\
\text { analytics. 'Town' economists value ro- } \\
\text { bustness and simplicity in techniques } \\
\text { more than elegance, and may develop } \\
\text { a certain sweeping skepticism regard- } \\
\text { ing elaborate formal tools. }\end{array}$ & $\begin{array}{l}\text { The focus is on publication of use- } \\
\text { ful and, at the same time, academ- } \\
\text { ically elegant model-based analyses. } \\
\text { There is generally an expectation that } \\
\text { the most advanced tools will be used, } \\
\text { rather than theoretically second-best, } \\
\text { if more robust, techniques. [See Sum- } \\
\text { mers (1991).] Published critique of } \\
\text { advanced tools is conventionally lim- } \\
\text { ited to points of narrow technicality. } \\
\text { These are reasons that explain the rar- } \\
\text { ity of 'town' economists' publications } \\
\text { in the scholarly journals of economet- } \\
\text { rics. }\end{array}$ \\
\hline $\mathrm{F}$ & $\begin{array}{l}\text { Professional } \\
\text { development }\end{array}$ & $\begin{array}{l}\text { Work pressures and difficulty of ac- } \\
\text { cess to academic programs restrict } \\
\text { opportunities for upgrading technical } \\
\text { knowledge. }\end{array}$ & $\begin{array}{l}\text { The academic milieu offers continuous } \\
\text { opportunity for upgrading of technical } \\
\text { knowledge. }\end{array}$ \\
\hline
\end{tabular}

memoranda, both formal and informal, oral briefings, formal presentations to managers, confidential client reports, and articles for 'trade' publications are just some of the diverse forms of reporting regularly used by economists in business and government.

Given the difficulty, and, indeed, in some cases, the impossibility, of following up the content of such diverse reportage for a substantial number of individuals, I chose instead to interview them and, through the interviews, to discover what value they placed on econometric methods.

This study, then, draws its evidence from in-depth interviews with 50 Australian economists in business and government, most of them in senior positions. This evidence is compared with the academic approach to quantitative work, as reported in the scholarly publications of economics and econometrics, with which I am closely acquainted after 30 years as an academic econometrician.

For cogency I have focused my inquiry on one specific field in which there is widespread quantitative analytical activity: the Australian housing sector. I have chosen the housing sector as a case study for a number of reasons: 
Table 2. Nine separation indicators

'Town' economists, as a group, typically have:

\begin{tabular}{|c|c|c|}
\hline$[1]$ & $\begin{array}{l}\text { a relatively narrow range of focal economic projects in } \\
\text { each sector/market being analysed. }\end{array}$ & $\mathrm{A}$ \\
\hline$[2]$ & $\begin{array}{l}\text { a tendency to prefer purely judgmental techniques to } \\
\text { model-based techniques for quantitative analyses, espe- } \\
\text { cially for the immediate short-run. }\end{array}$ & $\mathrm{B}, \mathrm{E}$ \\
\hline$[3]$ & $\begin{array}{l}\text { profound institutional knowledge about the sec- } \\
\text { tors/markets analysed. }\end{array}$ & $\mathrm{C}$ \\
\hline$[4]$ & $\begin{array}{l}\text { constant concern for data accuracy, reliability and time- } \\
\text { liness. }\end{array}$ & $\mathrm{C}$ \\
\hline$[5]$ & clients who are not quantitatively skilled. & $\mathrm{D}$ \\
\hline$[6]$ & $\begin{array}{l}\text { little regard for the use of elaborate econometric tech- } \\
\text { niques. }\end{array}$ & $\mathrm{E}$ \\
\hline$[7]$ & $\begin{array}{l}\text { no incentive to publish quantitative work in the scholarly } \\
\text { literature. }\end{array}$ & $\mathrm{E}$ \\
\hline$[8]$ & $\begin{array}{l}\text { no professional constraint on recording their critical } \\
\text { views regarding the practical effectiveness of econometric } \\
\text { theory. }\end{array}$ & $\mathrm{E}$ \\
\hline$[9]$ & $\begin{array}{l}\text { restricted time and opportunity for maintaining and up- } \\
\text { grading technical knowledge. }\end{array}$ & $\mathrm{F}$ \\
\hline
\end{tabular}

- the housing sector has many corporate and governmental participants (mortgage lenders, real estate agents, building materials suppliers, industry associations, government ministries, and so on), most of whom employ quantitatively-trained economists, so that there are many sources, each with its own perspective, from which to draw interviewees.

- quantitative work in housing economics raises a large variety of problems for econometricians (shortage of data, relatively weak microeconomic theory, unobservable central variables, market disequilibrium and structural change, to name a few), so that there is potential to see how a wide range of technical challenges are faced.

- sectoral institutions and salient issues in housing are similar in most developed countries. Conclusions from this study should therefore be generalisable beyond the Australian scene.

I see three logical alternatives for what my comparison of econometric activities in the academic and nonacademic worlds might reveal. They might be proceeding together in tandem, with one or the other of the parties in the lead as circumstances warrant. They might be, to some degree, 
separate. Or they might, in the sense already mentioned, be decisively split.

In reviewing the evidence, I shall take as my hypothesis the middle line, that applied econometric projects in the two worlds are, to some degree, separated activities. Strong evidence against this hypothesis, on the nine separation indicators, will be taken to imply the conclusion 'together in tandem'. Very strong evidence for the hypothesis on every one of the indicators would suggest an actual or imminent split.

\section{The Structure of This Paper}

What sources of evidence are there among 'town' economists on the nine separation indicators listed in Table 2? I shall look here at two kinds of sources: those relating to what 'town' economists do (and don't do) with econometrics ('their use of econometric methods'), and those relating to what they think of what they do (and can't do) with econometrics ('the value to them of econometric methods'). These are objective issues and subjective issues, respectively.

Interviewees' responses to the questions I asked under these two headings are analysed in section 5 and in sections 7 and 8, respectively. Each question contributes information on one or more of the separation indicators. The task is then to set the interviewees' responses - both individual and aggregated - beside the appropriate indicators. This is done in sections 6 and 9. The results are drawn together in section 10 and some concluding reflections are offered in section 11.

\section{Some Background on the Interviewees}

Assuring the credibility of the findings of an interview study demands the avoidance of anecdotal evidence and the reduction, as far as is possible, of the risk of bias across responses.

To get away from anecdotal evidence, it is important to ask practitioners to speak only about their own econometric work, and always to give an unembroidered account of that work. To minimise bias, it is important to maximise the response rate. In the present study there were no refusals - all the 50 economists approached agreed to participate. For minimising bias, it is also important to have the views of as broad a range of practitioners as possible. Breadth, in this context, means three things: broad sectoral coverage (i.e. interviewees in many different branches of the housing sector); broad locational coverage (i.e. interviewees in many different geographical 
locations); and broad experiential coverage (i.e. interviewees with little as well as long experience, and with nonspecialist as well as specialist training in econometrics).

\subsection{Sectoral coverage}

From the following eight categories of institutions with interest in the economics of the housing sector - I shall call them housing sector categories I interviewed the number of economists shown in brackets: ${ }^{2}$

(a) Housing and general economic consultants and research centres. (10)

(b) The Reserve Bank and trading banks. (9)

(c) Investment banks and funds managers. (11)

(d) Insurance companies. (3)

(e) Real estate agents. (2)

(f) Housing industry and real estate industry associations. (3)

(g) Building materials firms. (1)

(h) Government and semi-government departments, state and federal. (11)

\subsection{Locational and experiential coverage}

Interviews were held with economists in organisations based in Canberra, Melbourne and Sydney. This ensured that almost all the Australian housing sector institutions in categories (a), (b), (c), (f) and (h) that employ economists were reached. Within each institution I sought the economist principally concerned with the housing market. In $80 \%$ of cases this was the Chief Economist or Senior Economist. The interviewees' experience with applied econometric work ranged from a few months to 30 years, with a median of 12 years.

\subsection{How the interviews were conducted}

To give the interviews a broadly uniform structure and to guard against oversight in coverage of detail, I brought a printed questionnaire with me to the interviews. To preserve spontaneity in interviewees' responses, the 
questionnaire was not shown to them in advance. Most interviews lasted between 1.5 and 2 hours. All the interviewees were willing to explore issues in breadth and depth. Indeed, many took the initiative in this regard.

\subsection{Professional characteristics of the interviewees}

Of the 50 respondents ( 4 females and 46 males) who participated in this study, 29 are business economists, 11 are government economists, and 10 are from consulting organisations and nonacademic research centres. All 50 interviewees have some formal background in econometric theory (or a closely cognate discipline) and practical experience in the economic analysis of housing, using econometric tools.

All the interviewees hold a bachelor's degree, and with three exceptions it includes a major in economics. For simplicity, all 50 are referred to as 'economists' in this paper. More than half also hold a postgraduate degree (a doctorate in 7 cases, and a master's degree in 20 others).

On the basis of their years of professional econometric experience, the interviewees can be assigned to the three experience groups shown in Table 3 .

Table 3. Interviewees' professional experience

\begin{tabular}{|l|c|c|}
\hline Group & Years of experience & No. of economists \\
\hline $1 \mathrm{a}$ & $0-5$ & 15 \\
\hline $1 \mathrm{~b}$ & $6-10$ & 6 \\
\hline 2 & $11-20$ & 20 \\
\hline 3 & $21-30$ & 9 \\
\hline
\end{tabular}

\subsection{Interviewees' activities in the field of housing economics}

Table 4 summarises the 50 interviewees' current professional responsibilities in the field of housing economics. ${ }^{3}$ Of course, many have multiple responsibilities.

The starred rows in Table 4 indicate the 35 economists who are currently using econometric approaches to forecasting and/or modelling. The interviews revealed that 12 others rely exclusively or almost exclusively purely ${ }^{4}$ on expert judgment in their quantitative analyses. Of these 12, almost equal numbers are in each of the three experience groups (1-3), and they are fairly evenly spread across the eight sector categories (a)-(h). 4 of the 50 economists are not now involved in day-to-day econometric work. 
Table 4. Interviewees' current professional responsibilities

\begin{tabular}{|l|c|}
\hline Responsibility & $\begin{array}{c}\text { No. of } \\
\text { economists }\end{array}$ \\
\hline Monitoring the housing market and/or data gathering. & 44 \\
\hline Description and verbal analysis of economic conditions. & 44 \\
\hline Informal ('back-of-the-envelope') quantitative analyses. & 42 \\
\hline $\begin{array}{l}* \text { Forecasting using econometric methods (i.e. not by the } \\
\text { principal use of expert judgment) }\end{array}$ & 35 \\
\hline $\begin{array}{l}* \text { Formal quantitative modelling using econometric meth- } \\
\text { ods. }\end{array}$ & 30 \\
\hline $\begin{array}{l}\text { Consultative advice on government and/or industry quan- } \\
\text { titative policy making. }\end{array}$ & 24 \\
\hline $\begin{array}{l}\text { Direct input to government and/or industry quantitative } \\
\text { policy making. }\end{array}$ & 14 \\
\hline
\end{tabular}

\subsection{Who are their clients?}

Apart from advising their own employers, often at Board level, the business economists interviewed also provide economic commentary for industry associations and managers of major investment funds. Through appearances in the popular media, many of these people also shape the public's perception of economic trends in Australia. The government economists interviewed prepare advice for Ministers. Several also advise policy-makers in local government and in semi-government authorities. Some of the business and government economists interviewed serve together on the Indicative Planning Council for the Housing Industry, to formulate joint views on short- and long-term prospects for the industry as a whole.

It became clear from the interviews that, collectively, the 50 interviewees are extremely influential, in that (for example) spending decisions of the order of tens of millions of dollars are made on the strength, at least partly, of their quantitative economic advice.

I come now to the detailed evidence from the interviews. Readers interested only in my conclusions should go to section 6 , then to section 9 , and read on from there. 


\section{The Use of Econometric Methods by Economists: Objective Issues}

\subsection{Interviewees' recent projects involving quantitative work on housing}

43 of the interviewees reported quantitative projects in housing economics of recent or current interest to them. Table 5 groups these projects into 12 themes by the number of economists addressing each theme. Some interviewees reported more than one theme of interest. The multiplicity of forecasting studies among these themes is notable. The two most popular themes in Table 5 are of interest across most of the sector categories.

Table 5. The 12 principal themes of interest to interviewees

\begin{tabular}{|l|c|}
\hline Theme & $\begin{array}{c}\text { No. of } \\
\text { economists }\end{array}$ \\
\hline $\begin{array}{l}\text { Forecasting the number and value of housing commence- } \\
\text { ments (generally by region) as a way of forecasting } \\
\text { aggregate dwelling investment and GDP. }\end{array}$ & 13 \\
\hline $\begin{array}{l}\text { Modelling the influence of mortgage interest rate move- } \\
\text { ments on new housing construction, and on the stock of } \\
\text { credit outstanding in lending institutions. }\end{array}$ & 5 \\
\hline $\begin{array}{l}\text { Examining housing approvals and commencements as lead- } \\
\text { ing indicators of GDP. }\end{array}$ & 3 \\
\hline $\begin{array}{l}\text { Seeking determinants of the period and amplitude of hous- } \\
\text { ing cycles, as a means of explaining the currently delayed } \\
\text { cyclical downturn. }\end{array}$ & 3 \\
\hline Modelling the demand for land in Sydney. & 3 \\
\hline Forecasting median house prices by city. & 3 \\
\hline $\begin{array}{l}\text { Refining the forecasting of house prices by means of hedonic } \\
\text { modelling. }\end{array}$ & 2 \\
\hline The private and public rental markets for dwelling services. & 2 \\
\hline Forecasting revenues from conveyancing stamp duties. & 2 \\
\hline Construction of a 'housing affordability' index. & 1 \\
\hline The long run demand for housing. & 1 \\
\hline $\begin{array}{l}\text { Forecasting household formation as an input for determin- } \\
\text { ing housing demand. }\end{array}$ & \\
\hline
\end{tabular}




\subsection{Current awareness sources used}

The interviews sought information on the use of seven current awareness sources in housing economics and in econometric theory and technique. Table 6 shows how many economists rated each source as important for staying in touch with developments in each of the two fields. The first figure in columns 2 and 3 shows the number of economists rating each item as important. The second figure (in parentheses) shows the number, among those included in the first figure, rating each item as very important.

Table 6. Current awareness sources used

\begin{tabular}{|l|c|c|}
\hline Source & $\begin{array}{c}\text { Housing } \\
\text { economics }\end{array}$ & Econometrics \\
\hline $\begin{array}{l}\text { Reading papers produced within the or- } \\
\text { ganisation, or consultants' reports. }\end{array}$ & $18(11)$ & $6(4)$ \\
\hline Reading industry reports. & $46(23)$ & $1(1)$ \\
\hline Reading research working papers. & $18(1)$ & $11(4)$ \\
\hline Reading academic journals [see Note]. & $20(3)$ & $8(4)$ \\
\hline Reading books by academic authors. & $4(1)$ & $11(7)$ \\
\hline Attending seminars and conferences. & $25(8)$ & $7(1)$ \\
\hline Attending refresher courses. & $1(0)$ & $4(1)$ \\
\hline
\end{tabular}

Note to Table 6: The most frequently read journals (with about 25 mentions each) from a list of 24 put to interviewees are four Australian generalist economic journals. Then (but with an average of just 4 mentions each) come two international urban economics journals and one applied econometrics journal. Other journals were each read by 2 or fewer of the respondents.

The immediate impression from Table 6 is of the different orders of magnitude of the first figures in the two columns. Far more of the interviewees use current awareness sources in housing economics than in econometric theory and technique. In the housing area, the main resources by far are the publications of six particular industry consultative organisations. By contrast, eleven academic journals devoted to housing economics are hardly consulted at all.

The second feature of interest is that the most popular sources for econometrics are among the least popular for housing. The evidence indicates that there are virtually no expositions of modern econometric ideas in any industry publication, nor have these respondents collectively experienced more than a handful of work-based refresher courses in econometrics. 
The statistics seem to suggest books are useful to at least a few of the respondents for keeping up to date in econometrics. However, behind the figures is a stark fact: although 11 economists mentioned having recently looked at two or three books each, only 5 of those 11 people (and, more relevantly, only 5 of all the 50 economists interviewed) had looked at a comprehensive text of recent vintage, e.g. Maddala (1992) or Greene (1997), or a state-of-the-art survey, e.g. Charemza and Deadman (1997).

Most telling about the state of current awareness in econometrics, generally, among the interviewees is the fact that 28 of the 50 economists rated all seven current awareness sources on econometrics as of slight or no significance to them.

These 28 people are spread across experience groups as follows (with the percentage they represent of the group's size in parentheses): 8 are in group $1(38 \%), 11$ are in group $2(55 \%)$, and 9 are in group $3(100 \%)$. Perhaps not surprisingly, 12 of these 28 respondents are the people who report that their quantitative work is not model-based and rests entirely or almost entirely on expert judgment - see section 4.5, above.

Of course, the fact that so many economists make no use of any of the current awareness sources in econometrics may be saying something about the time they can spare for the purpose, and about the quality and usefulness to them of those sources. I shall return to these points in section 7.1, below.

\subsection{Econometric forecasting procedures used}

Nine alternative forecasting procedures appeared in the questionnaire. The numbers of economists who use each procedure are set out in Table 7. Some use more than one approach.

Notes to Table 7:

1. Bold face numbers may not be the sum of the light face numbers in each category because of double counting of individuals within the category.

2. Of the 33 who use a purely judgmental approach, 12 rely exclusively or almost exclusively on that approach.

3. Of the 20 who use atheoretical modelling, 13 also use a purely judgmental approach. Of the 32 who use behavioural modelling, 19 also use a purely judgmental approach.

4. Combining the two categories of model-based forecasts reveals that 35 people use one or both kinds of model-based approach.

5. 'Other methods' include use of leading indicators, and time series decomposition, with components separately projected. 
Table 7. Forecasting procedures used

\begin{tabular}{|l|c|c|}
\hline Judgmental (non-model-based) & & $\mathbf{3 3}$ [notes 1,2] \\
\hline Individual expert judgment. & 33 & \\
\hline $\begin{array}{l}\text { Consensus-based judgment (informal Delphi tech- } \\
\text { nique). }\end{array}$ & 13 & \\
\hline Atheoretical modelling (model-based) & & $\mathbf{2 0}$ [notes 3,4] \\
\hline Simple extrapolation. & 17 & \\
\hline Autoregressive modelling (e.g. Box-Jenkins). & 5 & \\
\hline Vector autoregressive (VAR) modelling. & 3 & \\
\hline Long-term curvilinear time trend fitting. & 5 & \\
\hline Behavioural modelling (model-based) & & $\mathbf{3 2}$ [notes 3,4] \\
\hline Single equation modelling. & 32 & \\
\hline Simultaneous equation modelling. & 8 & \\
\hline Other methods & & $\mathbf{6}$ [note 5] \\
\hline
\end{tabular}

Table 7 shows that purely judgmental and model-based forecasting methods are both popular. Clearly, there are good reasons for this. One approach may be most appropriate for one particular variable, a different approach for another. A variable which is highly volatile, susceptible to sudden large shocks, or poorly correlated with its ostensible determining variables will most likely be forecast judgmentally. Other factors which will militate against a model-based approach (especially a behavioural modelbased approach) are unavailability of high quality data and insufficient time for model building.

While the interview data show that choice of forecasting method is not systematically related to the respondent's housing sector category, that choice $i s$ related to the respondent's experience group. Moving from group 3 to group 1, there is a progressive tendency to avoid relying on expert judgment alone, and to prefer a modelling approach (yet with a willingness to apply judgmental adjustments to the model's output if they seem to be called for).

\subsection{Closer focus on statistical and econometric tools used}

\subsubsection{Model specification, estimation and prediction techniques}

Those economists who used behavioural models in their econometric work were asked about the kind of model specification they were most likely to employ in a quantitative analysis of housing. All replied in terms of a 
single equation, linear in the parameters. Fewer than a quarter of them contemplated also using any other form (e.g. a specification nonlinear in parameters, or involving simultaneous equations). Some respondents commented that this was, in part, on account of software limitations: 16 respondents never use statistical tools beyond those included in Lotus or Excel.

Respondents were asked which of eight well-established model-building techniques they used. Three of these relate to specification: the generalto-specific modelling approach, error-correction specification for dynamic models, and disequilibrium modelling. Four relate to estimation: ordinary least squares (respondents were also asked if they used this estimator only when it was theoretically legitimate), ridge regression, robust estimation, and Bayesian estimation. As well, interval predictions were asked about, since they are more informative than point predictions but are commonly passed over by 'town' economists, if only because their clients are strongly resistant to any quantitative result that is not single number!

Key to Table 8: Number of respondents who use:

$\begin{array}{llll}\text { a } & \text { general-to-specific modelling } & \mathbf{f} & \text { ridge regression } \\ \mathbf{b} & \text { error correction specification } & \text { g } & \text { robust estimation } \\ \text { c } & \text { disequilibrium modelling } & \text { h } & \text { Bayesian estimation } \\ \text { d } & \text { ordinary least squares (OLS) } & \text { i } & \text { formal prediction intervals } \\ \text { e } & \text { OLS, respecting its limitations } & & \end{array}$

Note: group sizes shown here are the relevant numbers, after omitting 15 people not involved in model building.

Table 8. Use of specification, estimation and prediction techniques

\begin{tabular}{|c|c|c|c|c|c|c|c|c|c|}
\hline Experience group & a & b & c & d & e & $\mathbf{f}$ & g & h & i \\
\hline Group 1a (size 12) & 5 & 7 & 1 & 9 & 4 & 0 & 0 & 1 & 4 \\
\hline Group 1b (size 5) & 0 & 0 & 1 & 5 & 1 & 0 & 0 & 1 & 1 \\
\hline Group 2 (size 13) & 3 & 2 & 0 & 13 & 1 & 1 & 1 & 1 & 2 \\
\hline Group 3 (size 5) & 0 & 1 & 1 & 4 & 0 & 0 & 0 & 0 & 0 \\
\hline
\end{tabular}

In Table 8, group 1a respondents show, as expected, most familiarity with recent developments in the academic literature - see columns a, b, e, i. However, columns c, f, g, h, and the data for groups 2 and 3 in all but column $\mathrm{d}$, indicate that simplicity of procedure is the norm among the respondents, especially those in the more senior groups. 


\subsubsection{Model testing techniques}

Respondents were asked which model testing and validation techniques they were accustomed to using. Procedures they mentioned were regression $\mathrm{R}$-squared, the sign of coefficients, diagnostic tests on residuals, and tests for structural shifts over time. All these procedures were already familiar in the early 1970s.

7 of the 32 economists using behavioural models also used some more recent model and disturbance specification test and evaluation methods. These include: a test for ARCH errors, the augmented Dickey-Fuller cointegration test, Lagrange Multiplier tests for restrictions on parameters, and the use of cross-validation, sensitivity analyses, and dynamic deterministic simulation. 5 of these 7 economists are, not surprisingly, from experience group 1a.

\subsection{Reporting of econometric work and its influence on clients}

Interviewees were asked in which documentary form their econometric work on housing was reported. 6 respondents judged this question as not relevant to their situation. The remaining 44 provided the information in Table 9 (with some respondents nominating more than one form of reporting).

Table 9. Written reporting of econometric work

\begin{tabular}{|l|c|}
\hline Medium of publication & No. of economists \\
\hline Internal reports, with restricted release. & 38 \\
\hline Reports for general circulation. & 25 \\
\hline $\begin{array}{l}\text { Research working papers (referencing academic lit- } \\
\text { erature). }\end{array}$ & 5 \\
\hline Publications in professional/industry magazines. & 5 \\
\hline Publications in academic journals. & 0 \\
\hline Publications as books. & 1 \\
\hline
\end{tabular}

The interviewees' separation from the academic literature, as publishers, is apparent - just as it was in the Note to Table 6, above, in the context of the interviewees as readers of the academic literature.

With their reports the interviewees influence the actions of their clients. This influence comes, they explained, from their past reputations for accurate analysis and their ability to provide an economic 'story', linking assumptions to conclusions, that is plausible in the real world (a view corroborated by Francis (1973), a central banker). The influence does not come 
from opening to clients' view the technical underpinnings of the analysis. Indeed, only 16 of the 44 respondents to this question judged any of their clients to be econometrically literate.

\section{A First Empirical Look at the Separation Phenomenon}

What do sections 5.1 to 5.5 contribute on the question of a separation between 'town' and 'gown' in the practice of econometrics? Each of these sections provides evidence on one or more of the separation indicators in Table 2. Let us now summarise this evidence.

Section 5.1 - Recent projects - links with indicator [1] ('A relatively narrow range of focal economic projects.'). We see the evidence in Table 5 where just two themes occupy proportionally far more economists than the other themes listed. The relative narrowness of the range spanned by all the projects in Table 5, moreover, can be gauged by comparison with the far broader view of empirical issues in housing economics that emerges from the comprehensive academic surveys by Olsen (1987), Smith et al. (1988) and Goodman (1989).

Section 5.2 - Current awareness - links with indicators [6] ('Little regard for the use of elaborate econometric techniques.') and [9] ('Restricted time and opportunity for maintaining and upgrading technical knowledge.'). Far fewer of the interviewees maintain their current awareness of developments in econometric technique than they do in housing economics. Further, those who were working to keep up, whether in housing or econometrics, did not generally assign high importance to academic sources. Finally, more than half were apparently doing nothing at all to maintain and upgrade their econometric knowledge. This inaction, many interviewees explained, was very much the outcome of an assessment of opportunity cost on their part (a point that is pursued further in sections 7.1 and 7.4, below).

Section 5.3 - Forecasting - links with indicators [2] ('A tendency to prefer purely judgmental techniques.') and [6]. The use of purely judgmental methods for forecasting is alive and well among the interviewees: 33 interviewees use them, 12 of these people doing so exclusively or almost exclusively. (Indeed, there were only 12 who make no use at all of purely judgmental forecasting.) On the other hand, model-based forecasting is by no means moribund, being used by 35 respondents.

Section 5.4 - Closer focus on statistical and econometric tools used - links with indicator [6]. Almost all the interviewees avoid elaborate model specifications and the estimation and testing techniques that go with them in current econometric textbooks. The practitioners in group 1 are, as ex- 
pected, generally the most comfortable with other than traditional modelbuilding techniques and diagnostics.

Section 5.5 - Reporting and influence - links with indicators [5] ('Nonquantitative clients.') and [7] ('Not publishing in academic locations.'). None of the 50 interviewees had recently published a quantitative study on housing in a scholarly journal. More generally, many interviewees indicated that they had neither the time nor the inclination to prepare their economic analyses for academic publication. As to their client reports, they did not think there was virtue in explaining their econometrics to clients - except on special request - because by and large those clients were not econometrically literate.

Overall, we have so far some amount of support for six of the separation indicators: [1], [2], [5], [6], [7], [9]. How much support, exactly? That is a subjective matter but some reasonable objective benchmarks can be established nevertheless.

For any indicator, let us define three levels for the support it may show for the 'separation' hypothesis: weak, strong and very strong. We can reasonably define demarcation points between these levels of support in terms of the proportion of the 50 respondents whose activity is in line with what the indicator assesses.

Thus, for example, indicator [7] states that 'town' economists have no incentive to publish quantitative work in the scholarly literature. We may say that if $40(80 \%)$ or more of the 50 interviewees have not published their quantitative work in the scholarly literature, the indicator is very strongly supported. Then if $25(50 \%)$ or more (but fewer than $80 \%$ ) of the interviewees have not published in the scholarly literature, the indicator is strongly supported. Otherwise it is weakly supported. If fewer than 50 interviewees have responded on a particular point (for whatever reason), then the $50 \%$ and $80 \%$ values will be reckoned on the basis of the actual number of respondents. Further, if an indicator is strongly supported in several sections of the paper, it will be reasonable to judge it very strongly supported overall.

Then, at this stage of reviewing the evidence, my assessment of level of support, by indicator, is:
[1] strong
[5] strong
[7] very strong
[2] weak
[6] strong
[9] strong 


\section{The Value of Econometrics to Economists: Subjective Issues}

As already mentioned above, in section 3, the interviewees' views were sought on a number of subjective issues related to their use of econometrics. These views throw light on 'the thought behind the practice' and offer insight on the value the interviewees place on econometrics as a practical tool.

\subsection{Keeping up to date with new developments}

We saw in section 5.2 that relatively few of the interviewees use the standard current awareness sources for econometrics. Indeed, over half of them make virtually no use of any of the sources. Why is this so?

The unhesitating answer of 40 interviewees was shortage of time. Time is short, they concurred, because of the unrelenting pressure of their daily activities. Many respondents said that they have an informal network of professional people from whom they seek technical advice as needed. However, very few of these advisers, it appears, are academics. Some further obstacles to keeping up are summarised in section 7.4, below.

Reflecting on such obstacles, and, no doubt, also on their personal experiences, several respondents independently drew the same significant conclusion. Working as a 'town' economist 'basically, you run down your stock of human capital' $\{8\}^{5}$ and - the way things are today - 'there is little prospect of replenishment' $\{11\}^{6}$ This could change, respondents felt, if there were more in-house refresher courses designed specifically for busy practitioners.

What are the costs of failing to keep up with frontline academic research in econometrics? A widely-held view among respondents can be paraphrased thus: not a great deal, if you are competent in the basics and use a lot of expert judgment. Indeed, one respondent said firmly: 'lots of people who don't keep up still do well in the [applied economics] industry' $\{26\}$.

\subsection{When econometric results conflict with one's prior beliefs?}

It is a vexed question, sometimes, to resolve the issue when econometric results conflict with one's prior beliefs that are based on economic theory and institutional knowledge.

Several respondents leaned towards credence in their econometrics, for example: 
'Gut feelings can be wrong! It is commonly believed the housing cycle is seven years long. But look what's happening at present!' $\{38\}$ [Group 2]

'The issue is to find the source of the inconsistency. This may be in the data! Don't automatically trust your judgment.' $\{8\}$ [Group 2]

'Seek a theoretical economic linkage that might account for the unexpected result. If satisfied by this explanation, then accept the econometric result.' $\{27\}$ [Group 1a]

However, 21 out of 40 respondents favoured an outlook which sustains prior beliefs unless econometric results, derived from the use of robust techniques, throw serious doubt on those beliefs. Generally, responses revealed a vigorous skepticism, regardless of experience group, about the correctness of econometric results that conflict markedly with prior beliefs.

\subsection{Data sources and their deficiencies}

Interviewees were invited to comment on deficiencies in the availability, reliability and timeliness of the published data (from Australian Bureau of Statistics (ABS) and industry sources) that they use. 46 expressed a view. 14 of them were basically satisfied with the quality of the data they use. ${ }^{7}$ The other 32 respondents made the following principal criticisms, which, they said, were founded on long experience: (a) there are insufficient micro data on housing available for many of the quantitative analyses of greatest interest, (b) some ABS housing finance data are of quite doubtful reliability, (c) ABS census data are not released in a timely fashion, and (d) non-ABS data are often hard to access and poorly structured.

\subsection{Would use of more elaborate techniques improve the accu- racy of analyses?}

It is implicit in academic applications of econometrics that one should, and indeed rationally will, use the very latest appropriate econometric techniques. Among nonacademics, however, the logic of doing so is not at all self-evident. There are cost-benefit considerations of which 'town' economists are very conscious, as their responses to the question in the subheading make clear.

From individual comments one can assemble a representative view of the thinking of a business economist, contemplating using some new and advanced econometric technique. First the practitioner must feel persuaded 
that it will bring some real benefit, for example, greater resilience to outliers. Then a comprehensible source will have to be found from which to learn how to apply it. Thereafter, to be realistic, nothing will happen unless there is software available to implement the technique. Next, the practitioner must have some sense of the limitations of the technique, or he/she will be flying blind when it comes to correctly interpreting the results. Fifth, if the theoretical assumptions on which the technique rests are partly invalid in a particular application, the practitioner will want to know how to form an idea of the reliability to attach to the findings. Last, but by no means least, the practitioner will want to convince him/herself that such overall deficiencies as there may be in the data do not erode the extra benefits the technique claims to offer.

Small wonder, then, that contemplation does not often become reality for the 'town' economist.

Interpreting each respondent's comment for the degree of support it shows for the proposition 'if you were to use more elaborate econometric techniques, do you think that would improve the accuracy of your analyses/forecasts etc.?' yields Table 10 .

Table 10. Would more elaborate technique improve accuracy?

\begin{tabular}{|c|c|c|c|c|}
\hline Experience group & \multicolumn{4}{|c|}{ Response to the proposition } \\
\hline & Yes & Perhaps & No & $\begin{array}{c}\text { Uncommitted / } \\
\text { no response }\end{array}$ \\
\hline 1 (size 21) & 1 & 6 & 11 & 3 \\
\hline $2($ size 20$)$ & 1 & 4 & 11 & 4 \\
\hline $3($ size 9$)$ & 0 & 4 & 3 & 2 \\
\hline
\end{tabular}

Doubt about the usefulness of elaborate techniques is clear. It is also clear that this doubt is not confined only to the more experienced economists. Younger practitioners, too, are very well aware that deficient data can seriously limit the value of elaborate techniques.

\subsection{Reflections on econometric education}

Interviewees were invited to reflect on what knowledge and skills, which they now saw as important, were inadequately or insufficiently presented during their university studies. 16 respondents thought that including more on the following themes was very desirable:

- applied work using local data sets - all 16 respondents mentioned this; 
- data problems (collection and quality issues, limitations of published data series);

- critical discussion of the philosophy of econometrics, and of modelling in particular;

- $\quad$ practice in replicating studies published by others;

- the limitations of econometric techniques.

\section{The Interviewees Sum Up: The Benefits and Failings of Econo- metrics}

In summing up the benefits and failings of econometrics as they saw them, the interviewees were, of course, influenced by their work settings. We have already seen in Table 1 how these tend to differ from those of academics. Not surprisingly, in view of point E in Table 1, the 'town' economists were more outspoken than one is accustomed academic econometricians to be when distinguishing ideal and reality in econometric practice.

Most respondents started off by citing the conventional view that an econometric approach is generally systematic, internally consistent, and objective, and that this endows its conclusions with greater credibility than those from judgmental inference. But, while expressing a positive view of what econometrics might contribute, they are cautious when it comes to realities. ${ }^{8}$

'Econometric methods are useful more for the background understanding they bring [about how to study quantitative relations between variables] than for their actual application. As a result one knows how to start looking for things, and what to question. This guidance in turn refines the econometric analyses.' $\{11\}$

'The econometric approach has value for disciplining thinking, but it is not very accurate in predicting cyclical turning points on the Australian economic scene.' $\{14\}$

'There is enormous pressure always for short term assessments. Econometrics is not very effective for such "short-termism" .' $\{30\}$

\section{What Picture Emerges?}

Let us see now how sections 7 and 8 relate to the nine 'separation' indicators of Table 2 . 
Section 7.1 - Keeping up to date - links with indicators [6] ('Little regard for the use of elaborate econometric techniques.') and [9] ('Restricted time and opportunity for maintaining and upgrading technical knowledge.'). 40 respondents were emphatic that time and opportunity for keeping up to date in econometrics were severely limited. They also implied that not keeping up to date didn't seem to affect the standing of those several economists who did without elaborate technique.

Section 7.2 - Conflict between econometric results and personal priors links with indicator [3] ('Profound institutional knowledge.'). 21 out of 40 respondents said they tended to favour their personal priors based on their institutional knowledge.

Section 7.3 - Data deficiencies - links with indicator [4] ('Constant concern for data accuracy, reliability and timeliness.'). 32 of 46 respondents on this matter had major concerns about housing data availability and quality, and emphasised the difficulty of modelling with poor data.

Section 7.4 - Would use of more elaborate techniques improve the accuracy of analyses? - links with indicator [6]. Only 2 of 41 respondents gave an unequivocal 'yes' to this important question. Generally, they expressed reservations about the usefulness of more elaborate techniques, especially in the context of data of deficient quality.

Section 7.5 - Reflections on econometric education - links with indicator [4]. A third of the interviewees emphasised the lack of opportunity, in their econometrics courses, to gain experience in handling real-world data and to learn about problems of data quality, both now matters of significance to them in their professional work.

Section 8 - The benefits and failings of econometrics - links with indicator [8] ('No professional constraint on recording critical views regarding the practical effectiveness of econometric theory.'). More than half the interviewees made quite clear their belief that there is a gap between what textbook econometric methods promise and what can be reliably achieved with them.

Summarising, we find in sections 7 and 8, evidence in support of indicators [3], [4], [6], [8] and [9]. Applying the criteria for degree of support set out in section 6 to this evidence, I judge the support under each indicator for the 'separation' hypothesis to be:
[3] strong
[6] very strong
[4] strong
[8] strong
[9] very strong 


\section{Conclusion}

Drawing together this appraisal and that relating to indicators [1], [2], [5], [6], [7] and [9], which was given in section 6 , I would evaluate the overall evidence on each of the nine indicators for the 'separation' hypothesis thus:
[1] strong
[4] strong
[2] weak
[5] strong
[7] very strong
[3] strong
[6] very strong
[8] strong
[9] very strong

Collectively, this represents very clear and detailed empirical support for the view that the worlds of the quantitative economist in business and government and the quantitative economist in academia are 'separated', in the sense described in section 1. Particularly notable is the strength of the evidence attached to indicators [6], [7] and [9].

Does the separation at present constitute a split? I would say the overall evidence here is not strong enough for that. However, if the separation continues to widen in the coming years, a split will become increasingly inevitable.

\section{Reflections on Combatting 'Separation' in the Practice of Econometrics}

It will be constructive to end by reflecting a little on some undesirable consequences of the 'separation' for which this paper has presented marked evidence. What will happen if nothing is done about it? What might be done about it?

The separation in the worlds of economists in 'town' and 'gown' is sustained by professional differences in attitudes to the use of econometric tools and in values regarding the aims of the analyses that are done. So long as these differences prevail, the separation will continue. Indeed further evolution of econometric formalism in academia (in theory and practice) and continued disregard of formalism by practitioners in business and government are together likely to precipitate a split. The consequences of that are likely to be uncongenial to all parties.

Most vulnerable will be the new graduates, hardly practised during their studies in those skills so apparently valued by quantitative economists in town, yet hardly able to influence the academic course designers in that direction. Negative perceptions are speedily disseminated, and the annual inflow of interested students into econometrics is likely to dwindle. This may, in turn, affect the viability of educational programs in the discipline. 
Vulnerable also, ultimately, are the business economists, whose persistence with superseded (and sometimes demonstrably inferior) quantitative techniques $^{9}$ will eventually have repercussions on employment, should financial setbacks on repeated occasions be directly attributable to poor quantitative economic advice. This may, further, undermine the high regard in which such advice is generally held today.

It is clear that all parties stand to gain by retreating from a threatened split.

Some of the economists I interviewed saw the danger of a widening gap between themselves and academia and claimed to be redressing the situation. Their remedy was to employ newly graduated Bachelors of Economics/Commerce, with a major in econometrics, to bring in skills in the use of modern econometric methods. This is useful, but it cannot be the answer in the longer run. A decade and more ago, a good new econometrics graduate could have a rounded view of empirically useful techniques from the forefront of the research literature. Today this is unlikely to occur: the research frontier in econometrics has already moved well beyond the furthest point reached in a specialised bachelor's degree and even a master's degree. And those who press on with the discipline to doctoral level are more likely to remain in academia.

While this particular solution is unlikely to be effective in the future, the idea that motivated it - of bringing the two worlds closer together - is not. How might that, indeed, be done effectively? There are two facets. Widening and deepening academic econometric knowledge among 'town' economists and feeding the lessons of empirical experience in business and government back to academic economists and to the econometric education programs in the universities. And there are two pathways: (i) subject matter elucidation and transfer via the printed or electronic word and (ii) personal and virtual encounter.

\subsection{Subject matter elucidation and transfer}

Two kinds of things are called for: detailed surveys of advanced econometric techniques, with illustrative real-world case studies, written specifically for a readership of 'town' economists; and widely-available channels through which these surveys can be accessed.

Such surveys need to be more than the high-level expositions one is accustomed to reading in the scholarly journals. They should be critical appraisals of the methods, with full acknowledgment (so far as is known) of their limitations and possible weaknesses in practice, and be written with simplified technicality. Few academic survey papers meet these objectives. 
Existing books may present a more promising model for what is needed. Indeed, two recent publications are pointers in the right direction. Oxley et al. (1995) is a book of nine surveys in econometrics which certainly meet the criteria of being accessible and critical, though a review of the robustness of techniques in practice is still mostly lacking. And Kennedy's (1998) excellent perspective on the structure of theory is a model for the design of the still unwritten work I am advocating, in the way of an overview of techniques in practice.

Standards are another aspect of the empirical use of econometric techniques that has been neglected. Standards are relevant both in the doing and the reporting of applied econometric work. Little has been done to formulate such standards, though already some time ago Sims (1982) and Los (1986) were pressing for progress. What is important, in setting standards, is that the wisdom of theorists, academic practitioners and nonacademic practitioners be pooled.

Getting hold of information of the above kind (when it is written!) and having it available where it is needed can be a problem. A contemporary solution in this context is to produce the information in CD-ROM form, taking advantage of a flexible hypertext format, and to bundle it with a user-friendly econometric software package.

Practitioners in business and government can benefit academia in a further way by offering their experienced views on priorities in the teaching of useful econometrics. These views can be made known through professional societies, through the practitioners' participation in Faculty visiting committees, and through signals to universities' graduate employment offices. 'Town' economists can also raise academic awareness of their viewpoints more broadly by documenting them in academic journals. The time has not only come for leading econometrics journals to commission penetrating critiques of theory and practice from the practitioner's point of view, it is overdue!

\subsection{Personal and virtual encounter}

The evidence from the present study indicates that there is little communication between economists in town and in academia. ${ }^{10}$ More open avenues are urgently needed: bringing the university to town and town to the university. Along the former avenue come professional refresher courses - giving meaning to the notion of 'lifelong learning' - as well as ongoing programs for the secondment of academics into business and government. Along the latter come business economists contributing to academic workshops on empirical themes, secondments of 'town' economists to academic research 
centres, and town-gown co-teaching of applied subjects in universities (see Hahn and Schmee (1987)). Several of these proposals would seem to be especially well suited to Web-based arrangements.

\subsection{Accreditation}

A more comprehensive rapprochement between practitioners in 'town' and 'gown' can be achieved through the creation of a national (and, eventually, international) professional institute of 'chartered econometricians' (or 'accredited econometricians'), in the mould of chartered accountants, chartered engineers and (most recently) chartered statisticians. Because such an institute would have authority, up to a point, to regulate activities in the profession, regardless of where its members worked, its professional standards and guidelines could effectively cut across separatist entrenched positions. I reiterate these words from section 1: as a split threatens, 'it seems to be no-one's responsibility to see to it that what evolves is good for the future of the discipline as a whole'. I see the professional institute as assuming that responsibility.

In addition to sponsoring and/or undertaking initiatives such as those mentioned earlier in this section, the institute, once established, should see to the collegial appraisal of existing econometric theory, in order to guide its members (and others) on what is and what is not likely to be empirically reliable. ${ }^{11} 12$

With activities, such as those outlined in this section, building bridges across the present divide, the signs of separation may well melt into memory.

\section{Acknowledgments}

I am grateful for the advice of Geoffrey Harcourt, Jan Kmenta, Robert Mellor, Murray Smith and Judy Yates. My greatest debt is to the fifty practitioners interviewed for this study, who gave me their time generously and were, without exception, frank, thoughtful and articulate in expressing their views. Their names and affiliations are available from the author at e.sowey@unsw.edu.au

\section{Notes}

1. I am specifically excluding here academic researchers in the role of business or government consultants. 
2. See the Acknowledgments for gaining information on who the interviewees are.

3. In this and following tables, it is possible that no entry gets the maximum frequency score of 50 . This may be because all 50 interviewees have responded, but not all of them are in involved in the same particular activity, or it may mean that not all 50 have responded usefully to the particular question.

4. There is emphasis here on the word 'purely', since interviewees may also make judgmental adjustments to model-based forecasts, where appropriate, before releasing them.

5. Each code number in curly brackets identifies a particular respondent. Space limitations preclude reproducing here all but a few of the memorably expressive remarks the respondents made during the interviews.

6. Younger economists see the same phenomenon, but in a different light! A respondent from group 1a said 'your econometric skills are a function of how recently you learned them. I am currently doing my Ph.D., so keeping up to date is not (yet) a problem' $\{7\}$.

7. However, 9 of these 14 were not involved with formal modelling and mostly relied on expert judgement for forecasting. This is not to say that everyone who relied on expert judgement was satisfied with their data.

8. This assessment of the discipline should not be lightly passed over, in view of the standing of the interviewees, as described in section 4.6.

9. It would be as if a surgeon were to persist with the operative techniques of the 1970s well into the new century.

10. See, in particular, section 5.5 and paragraph 2 of section 7.1.

11. The need for such guidance is highlighted also by Johnston (1992, p.52): “ ... the number of suggested estimation, testing and diagnostic procedures has proliferated ... certainly beyond the point where the average applied econometrician can hope to make sensible judgments about what research procedure to implement."

12. A similar international initiative in the field of medicine (the Cochrane Collaboration for evidence-based medicine) has been in progress since 1993. Its aims are documented in Chalmers and Altman (1995), and on many Websites.

\section{References}

1. J.C. Bailar, A larger perspective. American Statistician, 49: 10-11, 1995.

2. D. Banks, Is industrial statistics out of control? Statistical Science, 8: 356-377, 1993.

3. I. Chalmers and D.C. Altman (eds), Systematic Reviews. BMJ Publishing, London, 1995.

4. W.W. Charemza and D.F. Deadman, New Directions in Econometric Practice: General to Specific Modelling, Cointegration and Vector Autoregression. Elgar, London, 2nd edition, 1997.

5. D.R. Francis, The usefulness of applied econometrics to the policy maker. Federal Reserve Bank of St. Louis Review, 55 (no. 5): 7-10, May 1973.

6. A. Goodman, Topics in empirical urban housing research. 49-136 in R.F. Muth and A. Goodman, The Economics of Housing Markets. Harwood, New York, 1989.

7. W.H. Greene, Econometric Analysis. Macmillan, New York, 3rd edition, 1997.

8. R.E. Hagen, Ockam's razor, economics and the business client. Business Economics, 29 (no. 2): 48-52, 1994. 
9. G.J.Hahn and J. Schmee, Practitioner and academician co-teaching: an idea to consider. Proceedings of the ASA Section on Statistical Education 199-203, 1987.

10. D. Henderson, Innocence and Design: The Influence of Economic Ideas on Policy. Blackwell, Oxford, 1986.

11. T.W. Hutchison, Changing Aims in Economics. Blackwell, Oxford, 1992.

12. R.L. Iman, Partnerships among academe, industry and government. Amstat News, pp. 16, 18, October 1994.

13. J. Johnston, Econometrics: retrospect and prospect. 51-56 in J.D. Hey (ed), The Future of Economics, Cambridge University Press, Cambridge, 1992.

14. P. Kennedy, A Guide to Econometrics. Blackwell, New York, 4th edition, 1998.

15. C.A. Los, Quality control of empirical econometrics: a status report. Federal Reserve Bank of New York Research Paper 8606, April 1986.

16. G.S. Maddala, Introduction to Econometrics. Macmillan, New York, 2nd edition, 1992.

17. C. Moser, Statistics and public policy. Journal of the Royal Statistical Society (A), 143: 1-31, 1980.

18. H. Motamen-Scobie, The gap between the market practitioner and the theoretical and applied economist. Economic Modelling, 9: 306-312, 1992.

19. E.O. Olsen, Demand and supply of housing service: a critical survey of the empirical literature. 989-1022 in E.S. Mills (ed), Handbook of Regional and Urban Economics. Volume 2, North Holland, Amsterdam, 1987.

20. L. Oxley, D.A. George, C.J. Roberts and S. Sayer (eds), Surveys in Econometrics. Blackwell, Oxford, 1995.

21. C.A. Sims, Scientific standards in econometric modelling. Chapter 13 in M. Hazewinkel and A.H.G. Rinnooy Kan (eds), Current Developments in the Interface: Economics, Econometrics, Mathematics. Reidel, Amsterdam, 1982.

22. L.B. Smith, K.T. Rosen and G. Fallis, Recent developments in economic models of housing markets. Journal of Economic Literature 26: 29-64, 1988.

23. L.H. Summers, The scientific illusion in empirical macroeconomics. Scandinavian Journal of Economics 93: 129-148, 1991. 


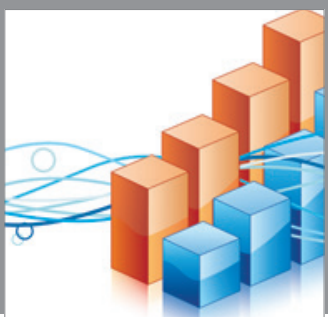

Advances in

Operations Research

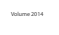

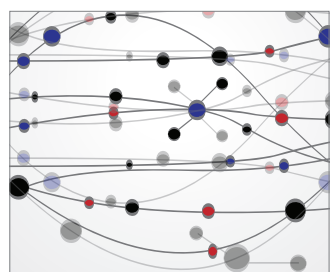

\section{The Scientific} World Journal
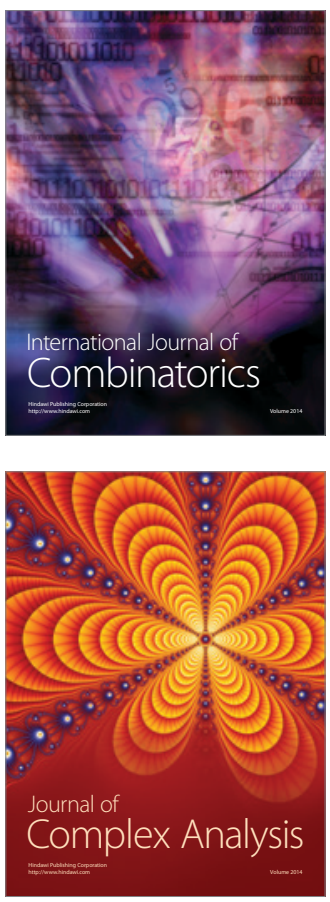

International Journal of

Mathematics and

Mathematical

Sciences
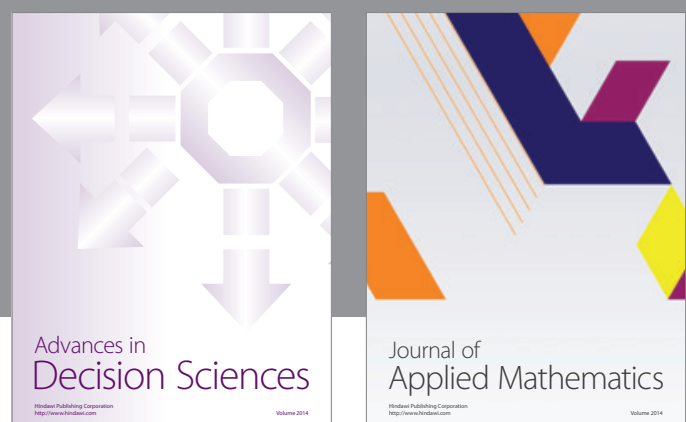

Journal of

Applied Mathematics
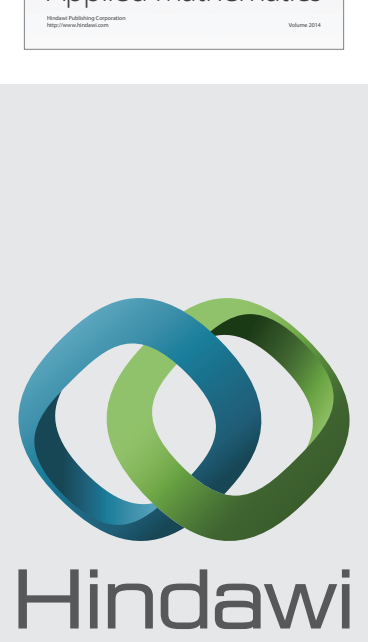

Submit your manuscripts at http://www.hindawi.com
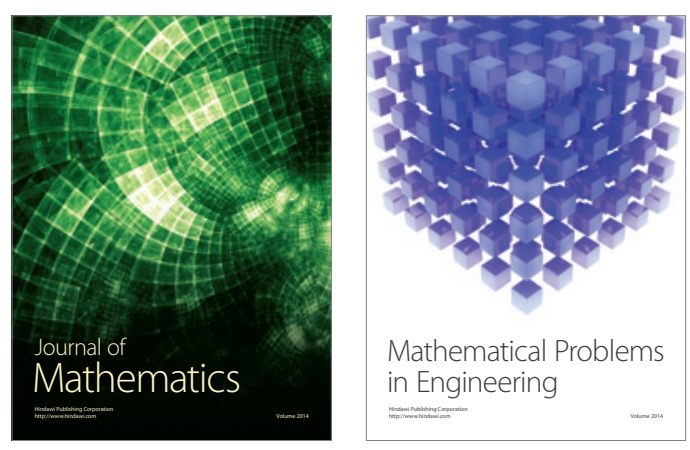

Mathematical Problems in Engineering
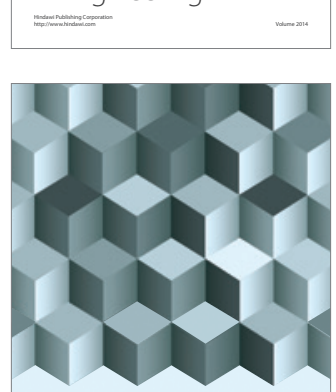

Journal of

Function Spaces
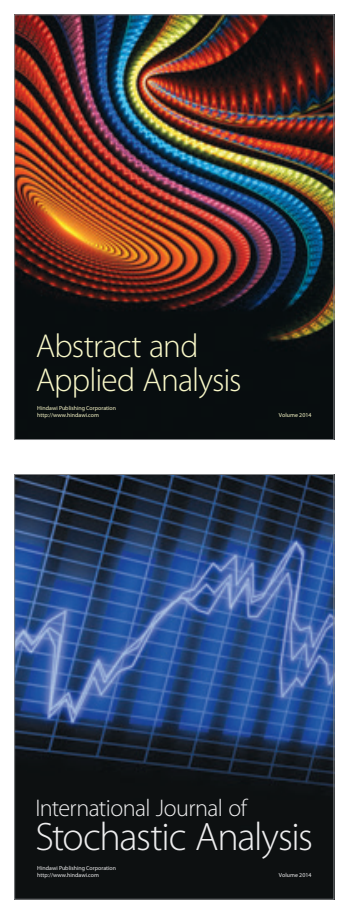

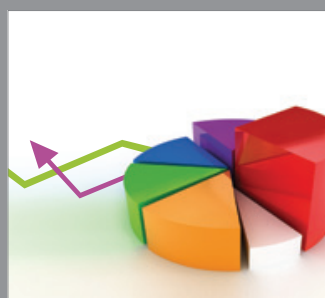

ournal of

Probability and Statistics

Promensencen
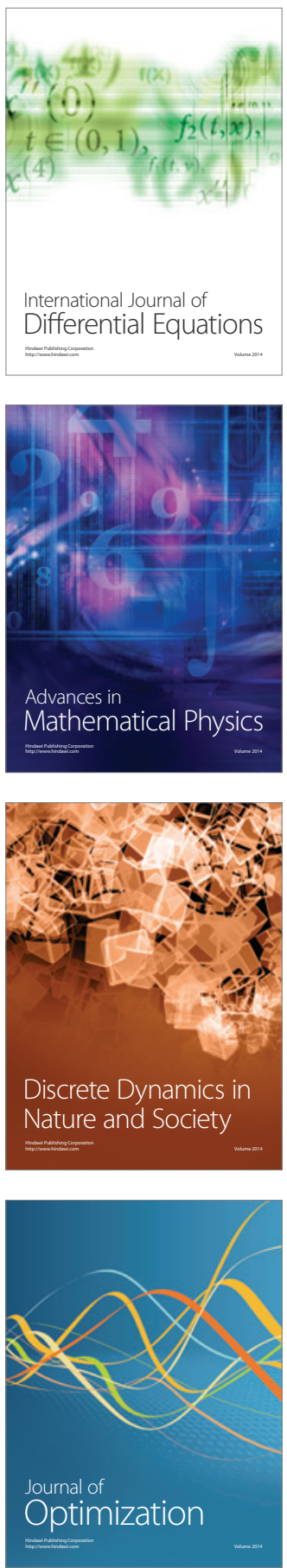